\title{
Reabilitação estética anterior pós-frenectomia: relato de caso
}

\author{
Previous aesthetic rehabilitation after frenectomy: \\ clinical case
}

\section{Rehabilitación estética anterior posible frenectomía: reporte de caso}

Jean Jacques da Silva ANDRADE ${ }^{1}$

Lioney Nobre CABRAL ${ }^{2}$

Odirlei Arruda MALASPINA ${ }^{3}$

${ }^{1}$ Acadêmico do Curso de Graduação em Odontologia, Escola Superior de Ciências da Saúde, Universidade do Estado do Amazonas, UEA, 69065-001 Manaus-AM, Brasil

${ }^{2}$ Professor Doutor das disciplinas de Patologia Bucal e Semiologia Odontológica II do Curso de Graduação em Odontologia, Escola Superior de Ciências da Saúde, Universidade do Estado do Amazonas, UEA, 69065-001 Manaus-AM, Brasil

${ }^{3}$ Professor Doutor das disciplinas de Dentística II e III, Clínica Integrada I e Estágio III do Curso de Graduação em Odontologia, Escola Superior de Ciências da Saúde, Universidade do Estado do Amazonas, UEA, 69065-001 Manaus-AM, Brasil

\section{Resumo}

O freio labial superior quando hipertrófico pode dificultar a higienização, restringir os movimentos de lábio, possibilitar acúmulo de placa bacteriana e prejudicar a fonética. Pode também gerar insatisfação estética para o paciente, além de poder causar diastema em interproxiamal dos incisivos. Este trabalho visa apresentar um caso clínico com um paciente de 17 anos de idade, com o freio labial superior hipertrófico associado a um diastema em interproximal dos incisivos. Houve indicação para remoção cirúrgica do freio labial antes do tratamento restaurador. A técnica de frenectomia escolhida foi a excisional simples. A intervenção cirúrgica foi necessária na remoção do freio labial hipertrófico, para a adequação do meio bucal, criando condições favoráveis ao fechamento do espaço entre os incisivos. Após a remoção do freio o paciente retornou para remoção de sutura e apresentou boa recuperação. Sendo assim também indicado para iniciar o tratamento restaurador estético para o fechamento do diastema.

Descritores: Freio Labial; Cirurgia Bucal; Diastema.

\begin{abstract}
The upper labial frenum when hypertrophic can make it difficult to sanitize, restrict the lip movements, allowing plaque buildup and undermine the phonetics. You can also generate aesthetic dissatisfaction to the patient, and can cause diastema in interproxiamal of the incisors. This work aims to present a clinical case with a 17-year-old patient, with the upper labial frenum hypertrophic associated with a diastema in the interproximal incisors. There was no indication for surgical removal of the labial frenum before the restorative treatment. Frenulectomy technique chosen was the simple excision. The surgery it was necessary for removal the labial frenum hypertrophic, for fitness of the oral environment, creating favorable conditions to closing the space between the incisors. After removing the frenum the patient returned for suture removal and showed good recovery. Thus also indicated to start the aesthetic restorative treatment for the closure of diastema.

Descriptors: Labial Frenum; Surgery, Oral; Diastema.

\section{Resumen}

El freno labial superior cuando hipertrófico puede dificultar la higienización, restringir los movimientos de labio, posibilitar la acumulación de placa bacteriana y perjudicar la fonética. También puede generar insatisfacción estética para el paciente, además de poder causar diastema en interproxiamal de los incisivos. Este trabajo tiene como objetivo presentar un caso clínico con un paciente de 17 años de edad, con el freno labial superior hipertrófico asociado a un diastema en interproximal de los incisivos. Se ha indicado la retirada quirúrgica del freno labial antes del tratamiento restaurador. La técnica de frenectomía elegida fue la escisión simple. La intervención quirúrgica fue necesaria en la remoción del freno labial hipertrófico, para la adecuación del medio bucal, creando condiciones favorables al cierre del espacio entre los incisivos. Después de la remoción del freno el paciente regresó para remoción de sutura y presentó buena recuperación. Siendo así también indicado para iniciar el tratamiento restaurador estético para el cierre del diastema.
\end{abstract}

Descriptores: Frenillo Labial; Cirugía Bucal; Diastema.

\section{INTRODUÇÃO}

O freio labial é uma dobra na membrana mucosa, geralmente de forma triangular, que vai do lábio superior ou inferior à mucosa alveolar, conectando uma estrutura móvel a outra fixa. Geralmente está localizado na linha mediana, entre incisivos centrais ${ }^{1}$.

O freio labial superior inicia-se na linha mediana da face interna labial e estende-se na linha de junção dos maxilares até a face externa do periósteo. Histologicamente é constituído de epitélio pavimentoso estratificado queratinizado na área de gengiva inserida e não queratinizado na porção vestibular, além de tecido conjuntivo frouxo altamente vascularizado ${ }^{2}$.

O nível das inserções pode variar da altura do vestíbulo à crista do rebordo alveolar e mesmo até a área da papila incisiva na maxila anterior. Com exceção do freio labial da linha média em associação com um diastema, inserções do freio geralmente não apresentam problemas quando a dentição está completa ${ }^{3}$.

Os freios labiais com inserção baixa, normalmente causam diastema entre incisivos centrais ${ }^{4}$. Este sendo definido como um espaço entre os dentes na maxila ou na mandíbula ${ }^{5}$. Quando ocorrente entre incisivos, avaliar ou pesquisar qual a causa etiológica: freio labial, mesiodens, hábito, fator hereditário ou ainda ausência de incisivos laterais ${ }^{4}$

A frenectomia é um procedimento cirúrgico que objetiva a remoção do freio, permitindo tanto a movimentação ortodôntica para o fechamento de diastemas, 
como a movimentação adequada da língua necessária às atividades funcionais. A remoção do freio lingual é freqüentemente solicitada pelo profissional fonoaudiólogo ${ }^{6}$.

O posicionamento anormal ou hipertrofia do freio labial superior pode dificultar a escovação dos dentes, retração dos tecidos gengivais, restrição dos movimentos labiais, interferindo na fonação e estética do paciente, e ainda pode estar relacionado ao diastema interincisal ${ }^{7}$.

Diante dessa possibilidade e com intento de obter uma estética satisfatória para redução de diastemas, podemos lançar mão de procedimento estético conservador, cabendo ressaltar que a Odontologia Estética Adesiva Contemporânea tem possibilitado entre outras palavras, a obtenção de restaurações estéticas adesivas fortemente unidas a estrutura dental ${ }^{8,9}$, principalmente quando realizados em esmalte dental ${ }^{8}$.

\section{REVISÃO DA LITERATURA}

$O$ freio labial superior origina-se na linha mediana da superfície interna do lábio. A sua origem é larga, mas o tecido do freio propriamente dito é estreito e insere-se na linha mediana da camada externa do periósteo e no tecido conjuntivo da sutura maxilar e do processo alveolar ${ }^{10}$. No recém-nascido, o freio labial freqüentemente tem sua inserção na região da papila palatina, o que é denominado de freio teto labial, podendo permanecer dessa forma até o final do período de dentição decídua ${ }^{11}$.

No entanto, no decorrer do período intertransitório da dentição mista e devido ao ganho de dimensão vertical gerada pela aposição óssea em toda extensão do rebordo alveolar, o freio labial deve migrar apicalmente de maneira gradual, assumindo uma nova inserção em direção a região vestibular. Mas se eventualmente a inserção do freio se mantiver na posição palatina originária, topograficamente esse freio deve ser considerado um desvio do padrão de normalidade e denominado de freio teto labial persistente ${ }^{12}$.

$\mathrm{O}$ freio labial, em muitos casos, está relacionado com a presença de diastema, gerando dificuldade na realização da higiene bucal, acúmulo de biofilme dentário, presença de gengivite, além da diminuição da quantidade de gengiva queratinizada. $\mathrm{O}$ freio lingual pode causar a anquiloglossia que acarreta uma série de perturbações funcionais e sociais ${ }^{6}$.

A frenectomia deve ser realizada precocemente, assim que obtido o diagnóstico, prevenindo ou minimizando as implicações relacionadas ao mau posicionamento dentário e ao desenvolvimento muscular, que pode ser prejudicado. Além do tratamento cirúrgico, a complementação através de tratamento ortodôntico e fonoaudiológico muitas vezes são necessários para restabelecer a fisiologia normal (oclusão, mastigação, deglutição e fonação) do complexo estomatognático. Salienta-se que, se não for realizado precocemente, pode comprometer o bem-estar psíquico-social ${ }^{6}$.

O freio labial persistente, com inserção baixa, fibroso e proeminente na maxila de crianças em dentição mista, embora seja um achado comum, muitas vezes é uma preocupação para os cirurgiões-dentistas, especialmente quando associado ao diastema interincisivos ${ }^{12}$. Clinicamente, além do diastema interincisivos, este freio persistente se caracteriza por causar isquemia da papila palatina quando tracionado. Outras condições clínicas indesejáveis podem estar presentes, quando a quantidade exagerada de tecido e a inserção baixa são capazes de interferir na escovação, dificultando a colocação da escova na altura própria do vestíbulo durante a limpeza convencional. Ainda, se as fibras musculares do freio inserirem-se no rebordo da gengiva marginal livre, distendendo o lábio durante a mastigação e a fala, podem causar retração no tecido do colo do dente, podendo provocar $\mathrm{o}$ acúmulo de restos de alimentos e, eventualmente, a formação de bolsas ${ }^{12}$

A decisão sobre o tratamento do freio labial deve ser tomada depois de cuidadosa avaliação, a fim de determinar se o resultado será desfavorável no caso de a condição persistir $^{13}$. Quando se optar pela frenectomia labial superior, a técnica menos traumática e preconizada atualmente é a técnica de reposicionamento de Chelotti ${ }^{14}$, cujo objetivo é a mudança da posição anatômica do freio, alterando suas características morfofuncionais e que proporciona o melhor resultado estético, eliminando apenas a porção do freio com inserção indesejável ${ }^{12}$, sem perda de estrutura periodontal (papila) ${ }^{7}$.

Em muitos casos de diastemas, a Ortodontia é, sem dúvida nenhuma, o tratamento de primeira escolha para o nivelamento e alinhamento dos dentes. Porém, em determinados casos, não ocorre à aceitação do paciente por este tipo de tratamento, devido ao longo prazo para o surgimento de resultados satisfatórios. Sendo assim, outras opções de tratamento devem estar disponíveis para atender todas às necessidades e exigências dos pacientes, como por exemplo, os procedimentos restauradores diretos ${ }^{15}$.

Outro detalhe bastante importante nesses casos é a análise da inserção do freio labial presente entre os incisivos centrais que, em muitos casos, é a causa do espaço presente entre os dentes centrais ${ }^{16}$. Nestes casos, o profissional também poderá utilizar recursos cirúrgicos para remoção de freio labial com inserção baixa que impede o fechamento do espaço presente entre os incisivos centrais superiores, sendo a frenectomia uma boa opção de tratamento quando esta associação ocorre ${ }^{17}$.

O principal problema do tratamento ortodôntico dos diastemas interincisivos consiste na estabilidade póstratamento quando a frenectomia não é realizada. Isso é explicado pelo fato de que, quando os incisivos são movimentados ortodonticamente, o tecido que estava entre eles fica acumulado. Diferentemente do tecido ósseo, o tecido gengival não sofre reabsorção em curto período de tempo. As fibras colágenas e elásticas são então comprimidas e ocorre uma força de reação que pode resultar recidiva do diastema ${ }^{18}$.

O considerável avanço dos meios de comunicação tem colaborado de forma significativa para o conhecimento, expectativa e exigência do paciente, frente às possibilidades estéticas que a Odontologia pode oferecer; esta condição tem levado os profissionais a se atualizarem e capacitarem, para a realização das mais diversas formas e novidades de tratamento odontológico ${ }^{19}$. Corroborando este levantamento, o tratamento multidisciplinar vem se tornando cada vez mais necessário e comum nos consultórios odontológicos principalmente para a resolução de casos clínicos de maior complexidade ${ }^{20}$.

A presença de diastemas acentuados na região anterior exige do profissional muita responsabilidade para escolher o tratamento mais adequado para atender as necessidades e as exigências do paciente. Sendo assim, o planejamento do caso deve ser uma abordagem criteriosa, incluindo conceitos multidisciplinares, para que o resultado final possa ser satisfatório ${ }^{21,22}$. Pois o fechamento de diastemas com resinas compostas, aplicadas de forma direta é uma técnica altamente conservadora, uma vez que não é necessário qualquer desgaste tecidual, antes da aplicação das massas de compósito ${ }^{23}$. 


\section{CASO CLÍNICO}

- Anamnese e Exame Clínico

Paciente de 17 anos de idade, gênero masculino, melanoderma, solteiro, apresentou-se em consulta à Policlínica Odontológica da Universidade do Estado do Amazonas (UEA) no dia 14 de abril de 2014, com indicação de um processo cirúrgico de frenectomia em diastema interincisivo, com queixa principal: o diastema está prejudicando a minha estética (SIC). Apresentava bom estado geral (BEG), nenhum distúrbio sistêmico, pressão arterial normal (P. A. 120x80 mmHg), não era fumante nem etilista e não possuía nenhum histórico de trauma na região.

Ao exame clínico intrabucal, observou-se o diastema interincisivo e o freio labial hipertrófico, que ao levantar o lábio superior, ocorreu também uma leve isquemia na região de papila dos incisivos centrais superiores (Figura 1).

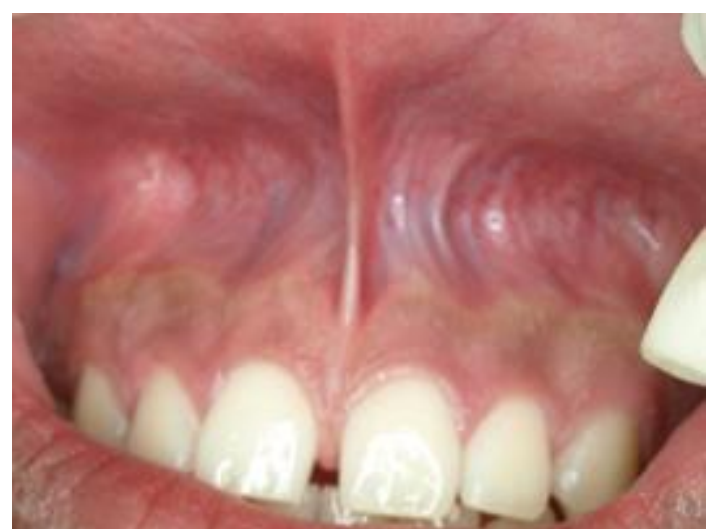

Figura 1: Freio labial em região de incisivos entre os elementos dentários 11 e 21 .

Realizou-se radiografia periapical dos elementos dentários 11 e 21, como exame complementar sugestivo, para confirmar o correto diagnóstico e verificar a existência de alguma lesão na região (Figura 2).

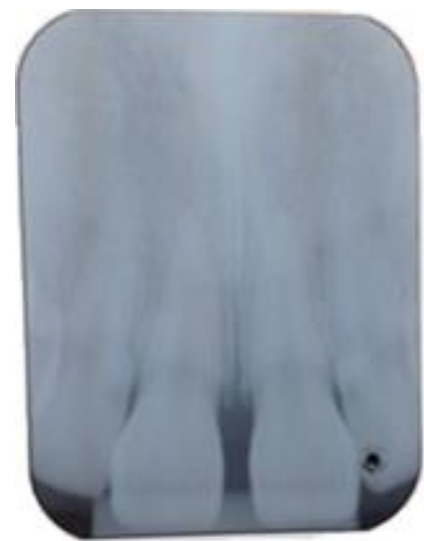

Figura 2: Radiografia periapical dos elementos dentários 11 e 21.

A radiografia periapical dos elementos 11 e 21, indicava nenhuma alteração patológica nas estruturas em questão, apenas o diastema medindo aproximadamente 2 $\mathrm{mm}$ de diâmetro. Sendo assim a radiografia periapical também ajudou ao correto diagnóstico para a realização de um plano de tratamento.

\section{- Plano de Tratamento Cirúrgico}

O paciente foi então submetido a um procedimento cirúrgico de frenectomia, A técnica de frenectomia escolhida foi a excisional simples. Fez-se a antissepsia peribucal como povidine (PVPI) e gaze estéril, com auxílio de uma pinça Pean, e a intraoral com bochecho de solução aquosa de digluconato de clorexidina a $0,12 \%$ por $1 \mathrm{~min}$.

A técnica anestésica escolhida foi a terminal infiltrativa em nervos alveolares superiores anteriores no fundo de sulco, bilateralmente, complementando na região de rebordo junto à inserção mais baixa do freio. A solução anestésica utilizada foi a lidocaína, $\mathrm{HCl}$ a $2 \%$ (clorohidrato de lidocaína) com epinefrina 1:100.000.
Com lâmina de bisturi número 15 foi realizada uma incisão elíptica estreita, ao redor da área do freio até o periósteo e o limite da sua inserção palatina (Figura 3). Após a incisão, foi realizado o deslocamento e remoção de fibras que se encontravam aderidas ao osso para liberar a inserção do freio.

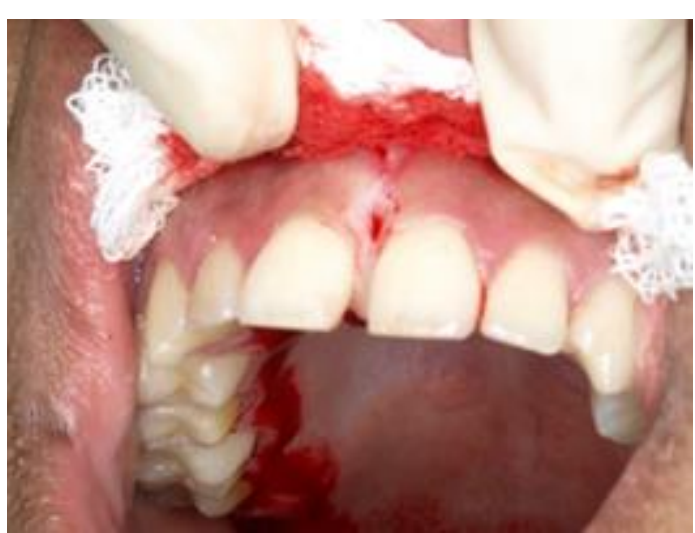

Figura 3: Freio labial com incisão elíptica estreita para remoção.

Realizou-se a sutura com pontos simples descontínuos, complementada com utilização de cimento cirúrgico para proteção (Figuras 4 e 5), que foram removidos após sete dias.

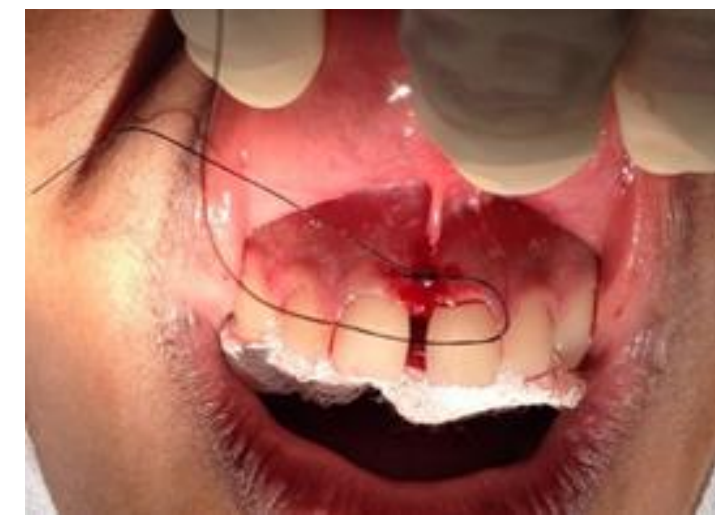

Figura 4. Sutura com pontos simples e descontinuo.

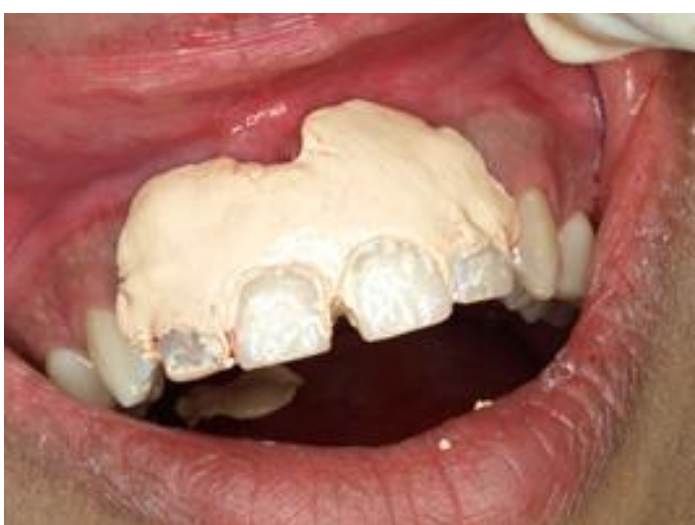

Figura 5. Colocação do cimento cirúrgico na região.

No caso de o paciente sentir dor pós-operatória foi feito o receituário de um analgésico de uso interno, via oral, Paracetamol 500mg, em comprimidos, de 6/6 horas por 3 dias. $O$ freio removido foi enviado para exame histopatológico. A peça cirúrgica foi acondicionada em um frasco contendo formol a $10 \%$, devidamente identificado, e encaminhado para o laboratório (Figura 6).

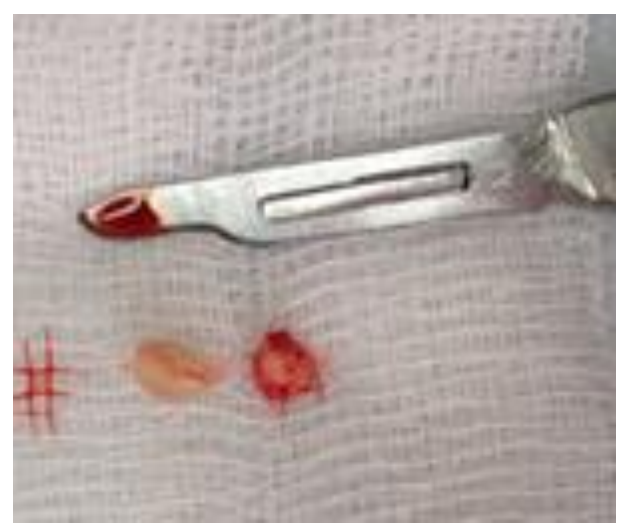

Figura 6: Freio labial removido. 


\section{○ Pós-Operatório}

Após quatorze dias o paciente retornou a Policlínica Odontológica da UEA para remoção do cimento cirúrgico e de sutura. Apresentou também uma evolução favorável do quadro, com uma cicatrização satisfatória (Figura 7).

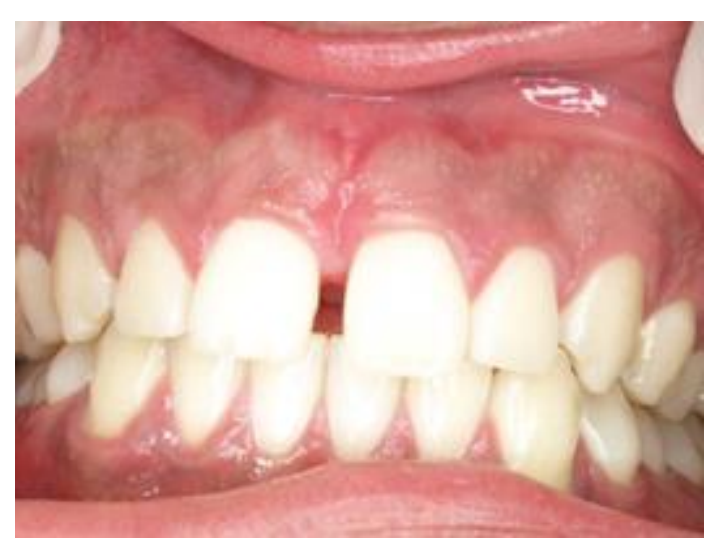

Figura 7: Pós-operatório (14 dias).

O estudo histopatológico revelou a mucosa do freio labial normal com epitélio estratificado pavimentoso paraceratinizado, lamina própria (tecido conjuntivo e fibras colágenas), nervos, vasos e uma leve inflamação crônica inespecífica com alguns linfócitos, próximo ao epitélio de sulco (Figuras 8 e 9).

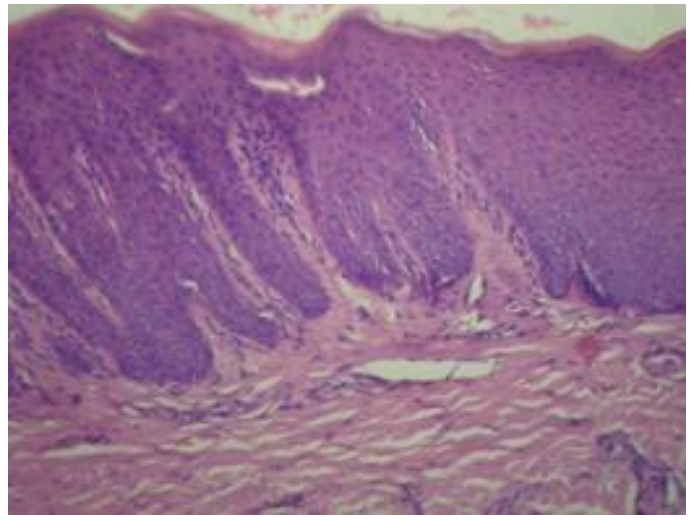

Figura 8: Mucosa do freio normal com epitélio estratificado pavimentoso paraceratinizado e lâmina própria (tecido conjuntivo e fibras colágenas)

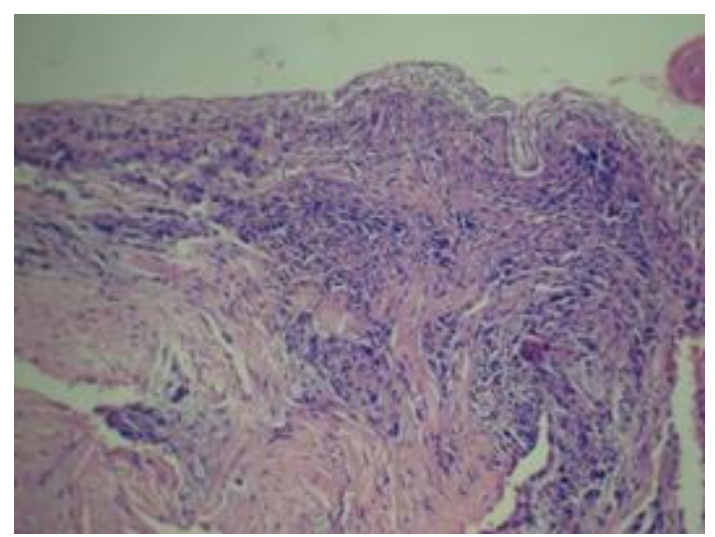

Figura 9: Leve inflamação crônica inespecífica com alguns linfócitos próximos ao epitélio de sulco.

Após um ano de proservação da cirurgia de frenectomia, o paciente iniciou o tratamento restaurador estético da região anterior. Para tanto, foi feito procedimento de moldagem com alginato para estudar o modelo e realizar o planejamento.

- Observações do modelo de estudo

Foi constatado através da observação dos modelos de estudo as seguintes alterações estéticas (Figura 10):

$\checkmark$ Diastema nos incisivos centrais com 2,4 mm

$\checkmark$ Diastema entre lateral e canino, dentes 12 e 13, com 1,4 $\mathrm{mm}$

$\checkmark$ Diastema entre lateral e canino, dentes 22 e 23, com 0,5 $\mathrm{mm}$

$\checkmark$ Alteração de posicionamento da coroa do elemento 21 com ligeira distalização da porção coronária incisal e rotação no sentido vestibular da porção distal.

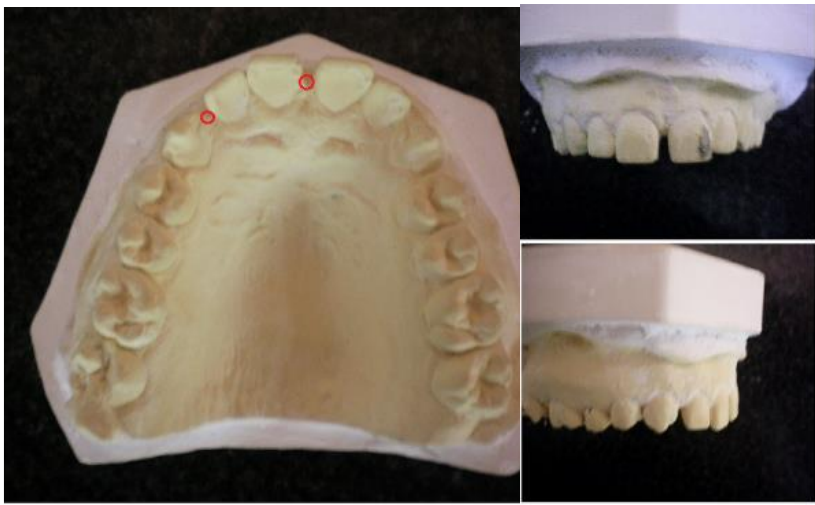

Figura 10: Modelo em gesso para o estudo do fechamento dos diastemas. Em destaque os círculos em vermelhos demonstrando os dois diastemas: um entre os incisivos centrais superiores e outro entre o incisivo lateral superior direito (elemento dentário 12) e o canino superior direito (elemento dentário 13).

\section{- Tratamento Restaurador Estético}

Após o estudo do modelo iniciou-se o procedimento restaurador, a técnica escolhida foi o emprego de materiais restauradores diretos (resina composta) pela a técnica da mão livre - para resolução dos diastemas - e remodelação cosmética por desgaste seletivo - para resolução do mal posicionamento coronário do elemento 21 .

Após a profilaxia, foi realizado o registro fotográfico do sorriso do paciente e das áreas com os diastemas utilizando afastador labial para fotografia (Figuras 11 a 13).

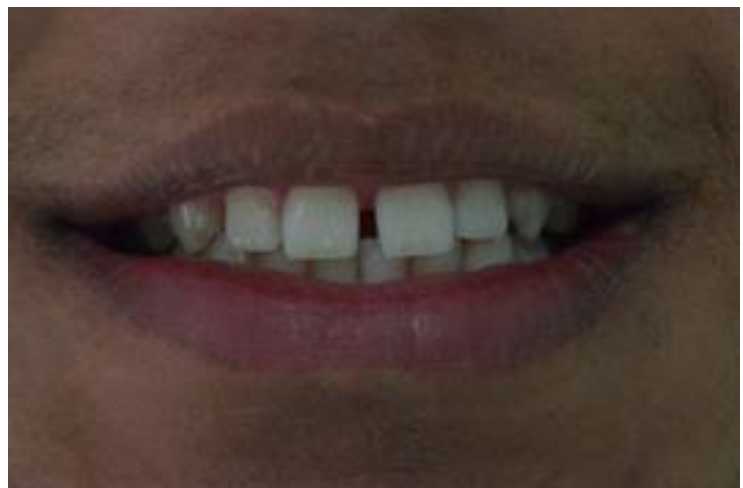

Figura 11: Sorriso inicial do paciente antes do procedimento restaurador.

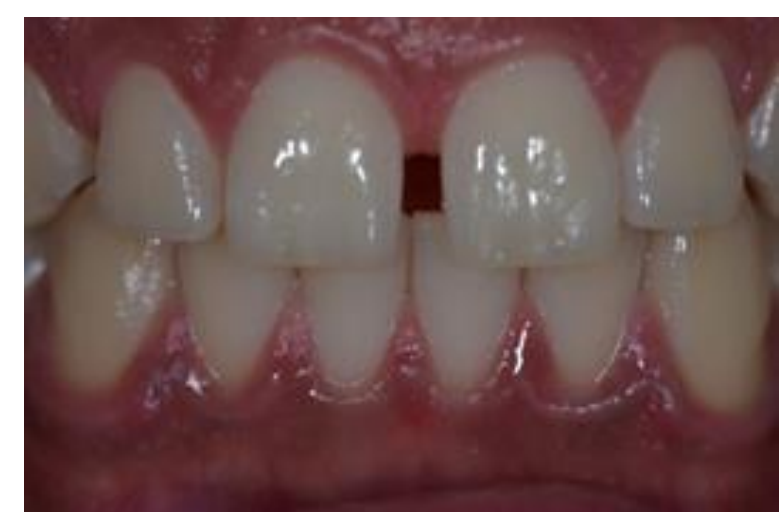

Figura 12: Fotografia evidenciando o diastema entre os incisivos centrais superiores.

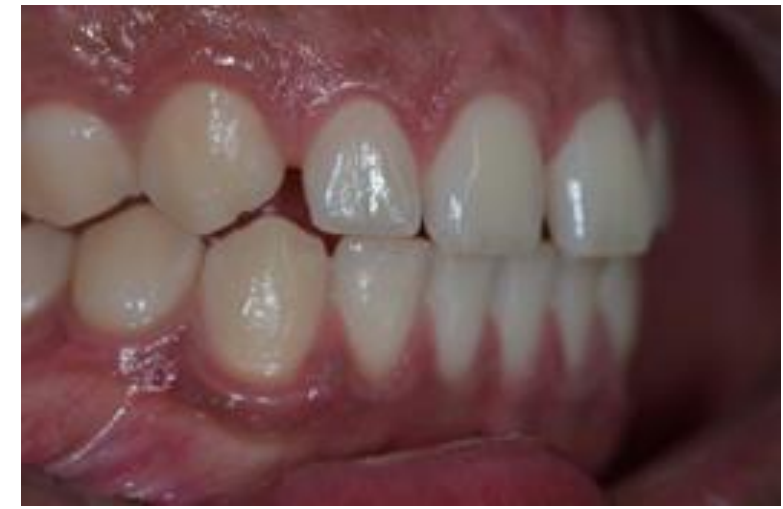

Figura 13: Fotografia evidenciando o diastema entre os elementos dentários 12 e 13.

Em seguida realizou-se seleção de cor da resina composta a ser utilizada, antes do isolamento absoluto em dentes limpos, sob luz natural, úmidos, na qual a resina foi posicionada no terço cervical. As resinas escolhidas foram: 
Filtek Z350 XT (3M ESPE, 3M do Brasil Ltda, Brasil) de cores A2B e A2E (Figura 14).

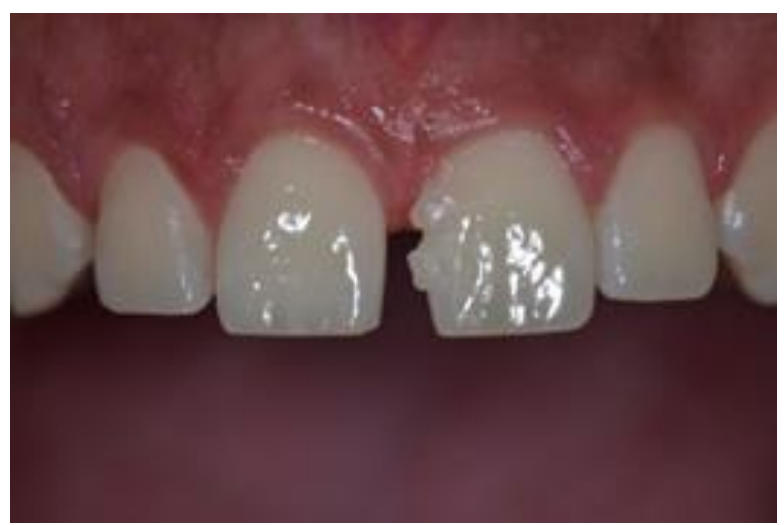

Figura 14: Seleção da cor da resina composta fotopolimerizável a ser utilizada nas cores A2B e A2E.

Após a seleção de cor da resina composta, iniciou-se o processo de isolamento absoluto do campo operatório. O lençol de borracha perfumado Airon (Maquira Industria de Produtos Odontológicos, Maringá, PR, Brasil) de cor azul e tamanho 13,5 x 13,5 cm, foi adaptado em um Arco Young. Em seguida o conjunto arco/lençol foi posicionado sobre a cavidade bucal e o lençol foi pressionado de encontro aos dentes que seriam isolados, até que seus contornos foram facilmente percebidos. Nesse momento com uma caneta de ponta úmida de cor preta, fez-se uma marcação sobre cada um dos dentes que serão isolados do elemento dentário 14 ao elemento dentário 24.

Em seguida o lençol de borracha foi perfurado com um Alicate perfurador Ainsworth, na região correspondente aos dentes que serão isolados, marcados com a caneta. Após a perfuração do lençol o conjunto arco/lençol foi levado com cuidado até os dentes correspondentes, assumindo sua posição marcada, estabilizando nos extremos com auxílio de um fio dental e uma pequena secção cortada do próprio lençol e inserida entre o elemento dentário 24 e o lençol. Para estabilizar o lençol de borracha no outro extremo utilizou-se um grampo 206, que foi posicionado e adaptado com uma Pinça porta grampo de Palmer no elemento dentário 14. O lençol de borracha em posição favorável foi então adaptado com auxílio de um fio dental deslizando nos pontos de contatos e interproximal de cada elemento dentário correspondente.

Após isolamento absoluto foi demarcada área no elemento dentário 21 que apresentava ligeira giroversão quando comparado ao elemento 11 , em razão de pequeno desvio no seu longo eixo coronal. Fez-se então demarcação da área de maior saliência e indicada a receber o tratamento remodelador por desgaste seletivo na porção do terço médio e distal da face vestibular do elemento dentário 21. Com broca 2135 FF da coleção ultra fina do Kit Fava (Fava Metalúrgica, São Paulo-Brasil) foi realizado desgaste seletivo do esmalte no elemento dentário 21 (Figuras 15 a 17).

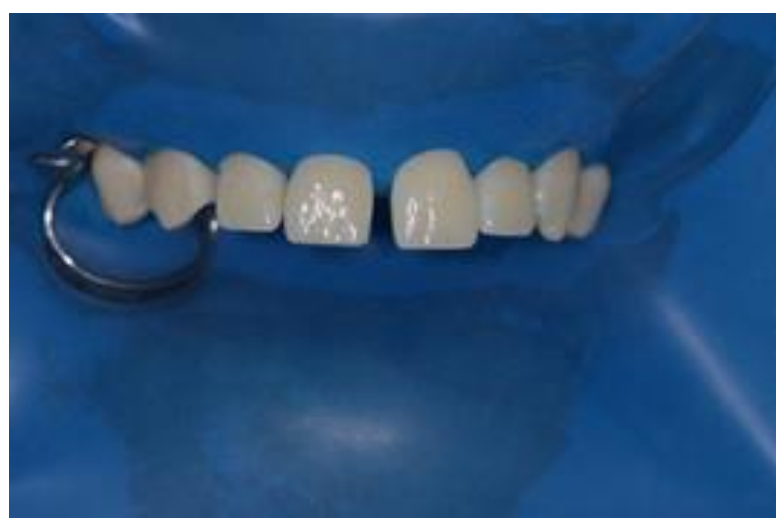

Figura 15: Isolamento absoluto com lençol de borracha e grampo 206 no elemento dentário 14.

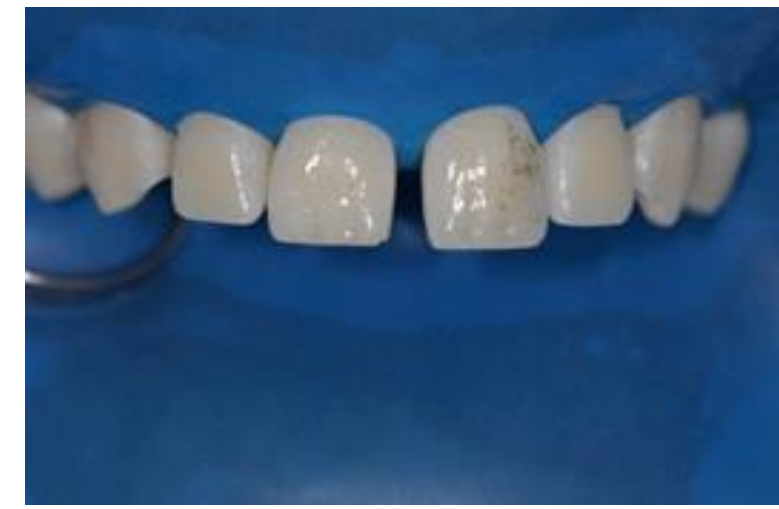

Figura 16: Demarcação da área nos terços médio e distal, da face vestibular, do elemento dentário 21 , a ser desgastada para ajuste e refino de medidas.

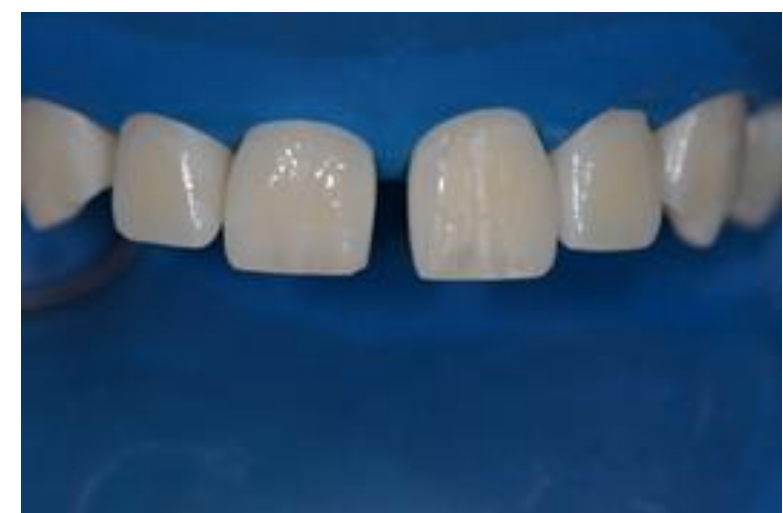

Figura 17: Área nos terços distal e médio da face vestibular, do elemento dentário 21, desgastada com broca FF, para leve ajuste e refino de medidas.

Em seguida foi realizado o condicionamento ácido, com attaque gel (Biodinâmica Europa S.L., Madrid, España) composto por gel de ácido ortofosfórico a 37\%, na região do diastema por 30 segundos (Figura 18).

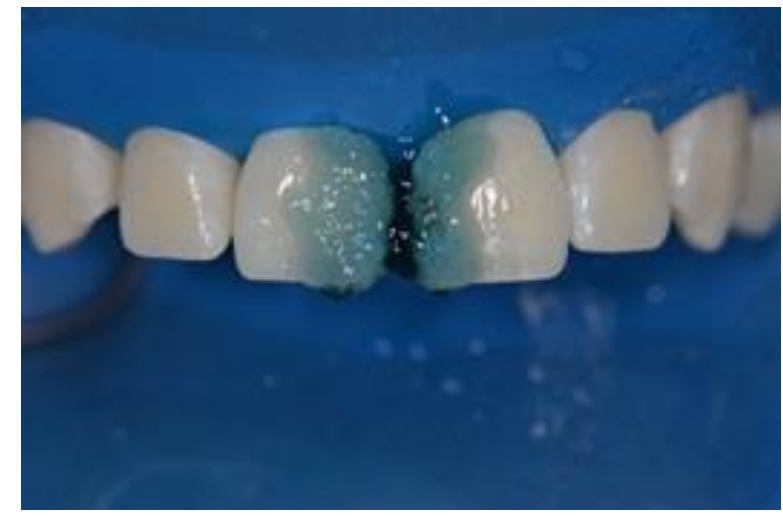

Figura 18: Condicionamento ácido, com gel de ácido ortofosfórico a $37 \%$, por 30 segundos.

Em seguida, lavou-se abundantemente com água a área condicionada por 30 segundos. E secou-se com jato de ar (Figura 19).

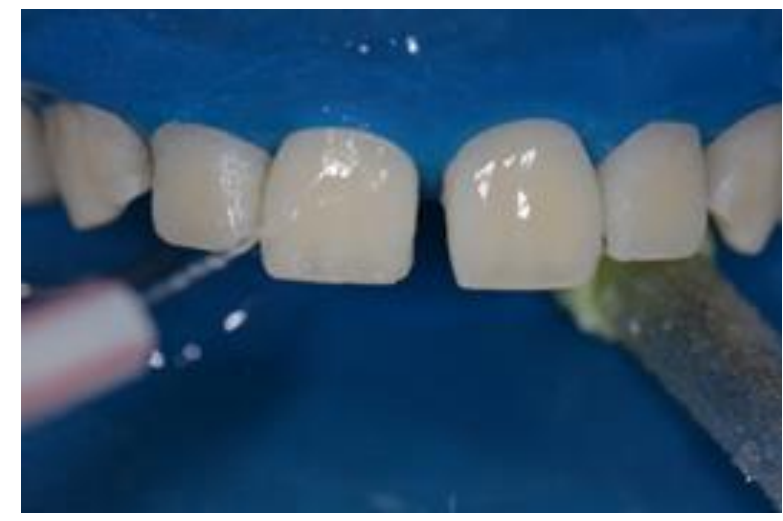

Figura 19: Lavagem com água, por 30 segundos, nas áreas condicionadas.

O sistema adesivo escolhido foi o Adesivo Adper Single Bond 2 (3M ESPE, 3M do Brasil Ltda, BRASIL). Com auxílio de um microbrush foram aplicadas duas camadas consecutivas do adesivo. Comum novo micro microbrush, foram removidos os excessos, formando uma 
camada uniforme e brilhante do adesivo que foi fotopolimerizada por 40 segundos.

A técnica escolhida para reconstrução da anatomia coronária prioriza a forma de contorno coroa dentária, assim pequenas e sucessivas camadas (até $2 \mathrm{~mm}$ ) de resina foram acomodadas na porção mesial do elemento 11 de tal sorte a se estabelecer a forma de contorno adequada do elemento (Figuras 20 e 21).

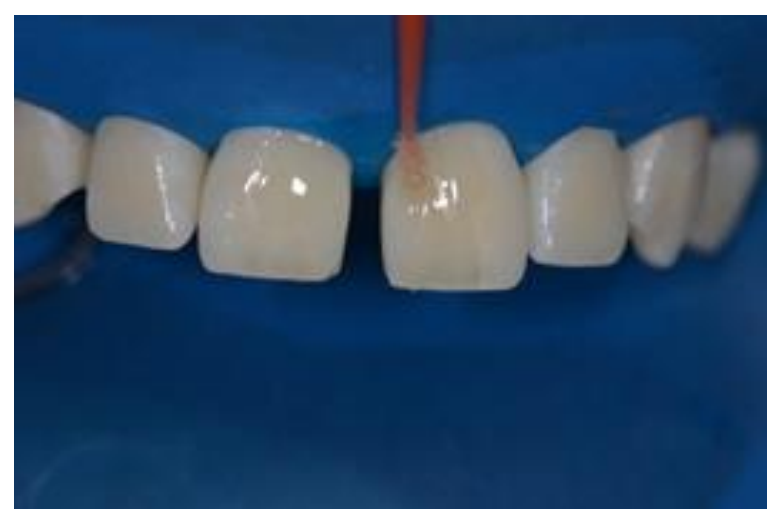

Figura 20: Aplicação do sistema adesivo fotopolimerizavel, com auxílio de microbrush.

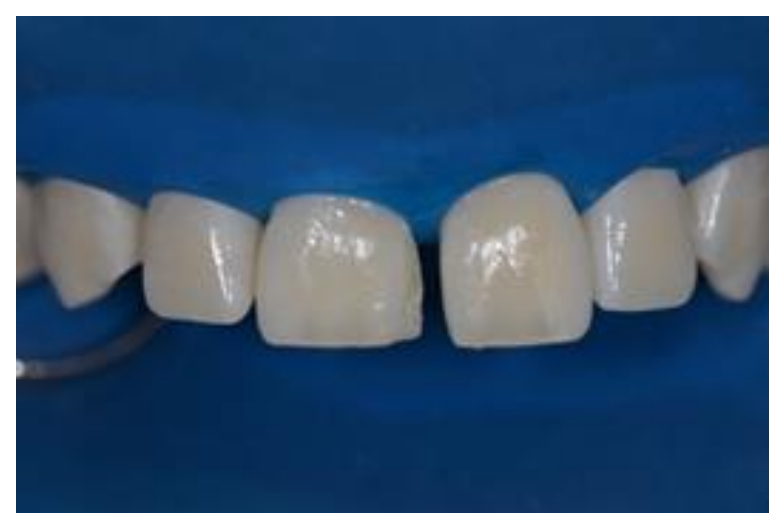

Figura 21: Construção da forma de contorno do elemento $11 \mathrm{com}$ adequada dimensão mesiodistal.

Com auxílio de uma tira de poliéster adaptada na face palatina do elemento dentário 11 , foram incrementadas pequenas porções de resina A2E. As pequenas porções de resina foram levadas de encontro ao dente, pressionadas e tracionadas com o auxílio da tira de poliéster contra o dente, de forma a esculpir o contorno palatino - Técnica da matriz tracionada. Após conseguido o contorno planejado para a restauração realizou-se a fotopolimerização.

Após ter atingido por palatina o contorno desejado para a restauração, iniciou-se o mesmo processo por vestibular, sucessivos incrementos de resina composta A2B foram inseridos e adequadamente acomodados, quando então eram fotopolimerizados.

Em seguida uma última camada foi aplicada por vestibular com objetivo de reproduzir as características do esmalte vestibular e proximal. Para atingir essa forma utilizou-se os pinceis especiais que colaboraram na obtenção de uma superfície lisa e de transição suave entre o material restaurador e o substrato dental. Na sequência realizou-se novamente a fotoativação (Figuras 22 e 23).

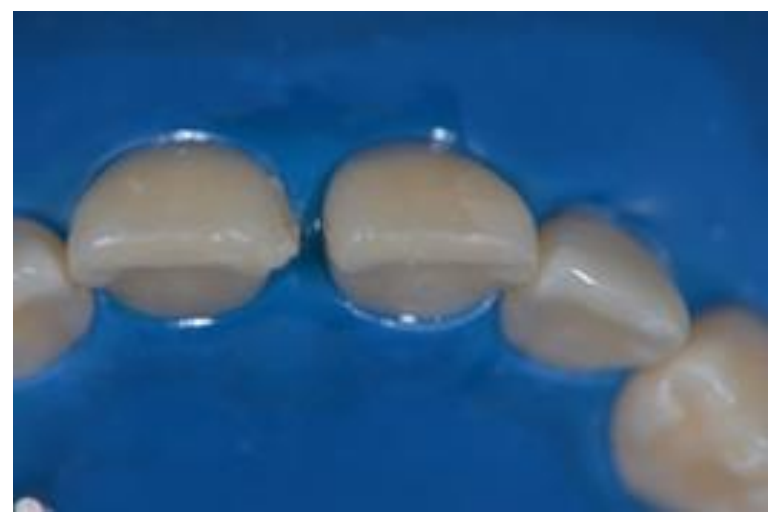

Figura 22: Visualização incisal da dimensão mesiodistal do elemento 11 , notar a ausência de contorno palatino.

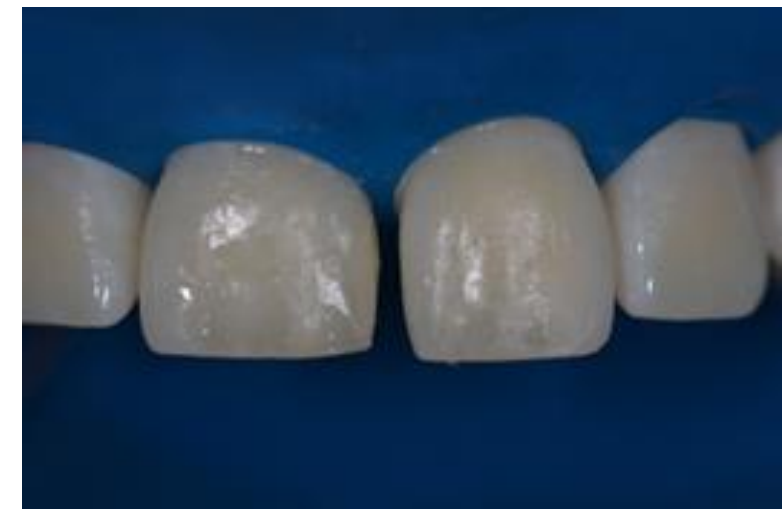

Figura 23: Construção da face vestibular e proximal, do elemento dentário 11, com resina composta fotopolimerizável, vista por vestibular

O próximo passo foi a conferência da largura do elemento dentário 11, o qual seria reproduzido nas medidas do elemento dentário 21. Para isso utilizou-se um compasso de ponta-seca para medir a largura do elemento dentário 11 , antes que $\mathrm{o}$ acabamento do mesmo fosse feito (Figuras 24 e 25).

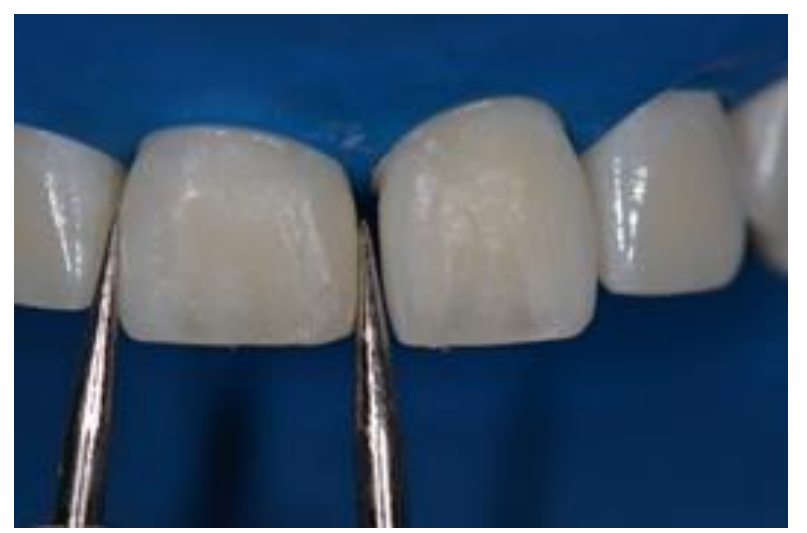

Figura 24: Utilização de compasso de ponta seca para medir a largura do elemento dentário 11, como parâmetro, após sua modificação.

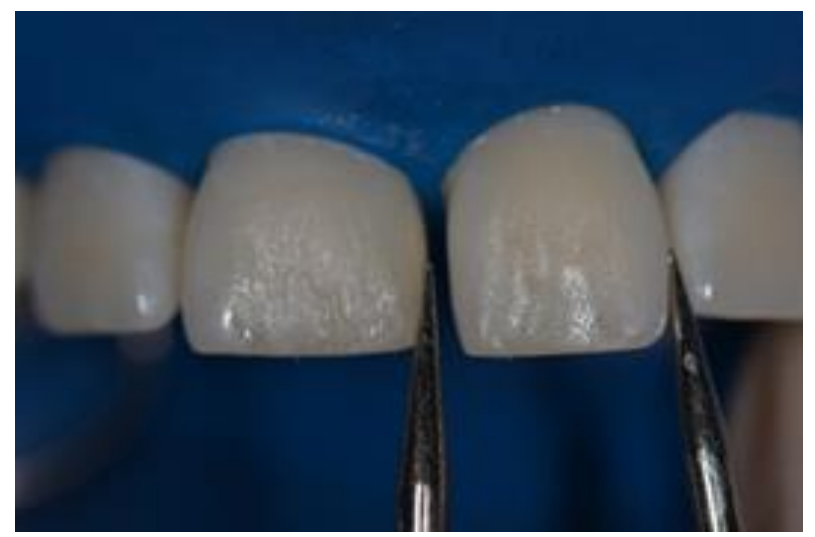

Figura 25: Utilização do compasso de ponta seca, com a medida de largura do elemento dentário 11, sendo levada para o elemento dentário 21.

Concluída a restauração no dente 11 , os mesmos procedimentos foram, agora realizados no dente 21 . Novamente foi utilizada a tira de poliéster e técnicas de incrementos de resinas idênticas a descrita no elemento dentário 11. De forma cautelosa sem produzir excessos que comprometam a saúde do periodonto (Figuras 26 e 27).

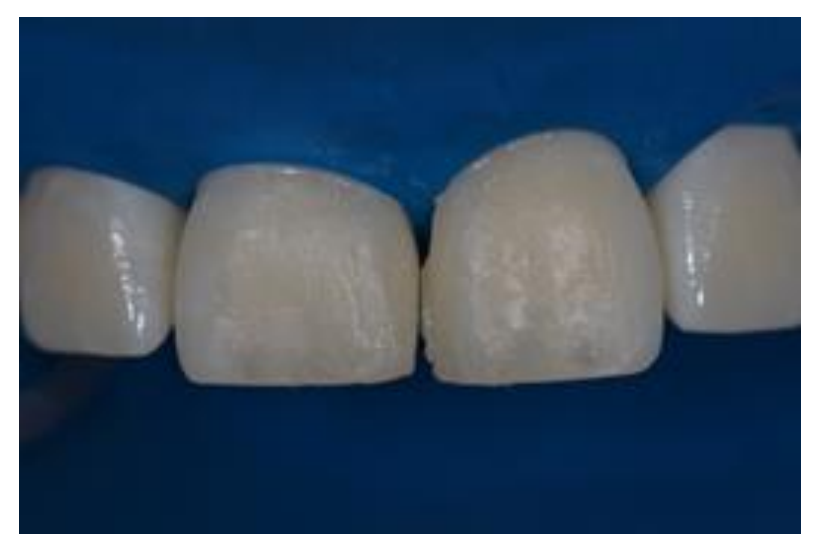

Figura 26: Construção do ponto de contato entre os elementos 11 e 21 com resina composta fotopolimerizável, vista por vestibular. 


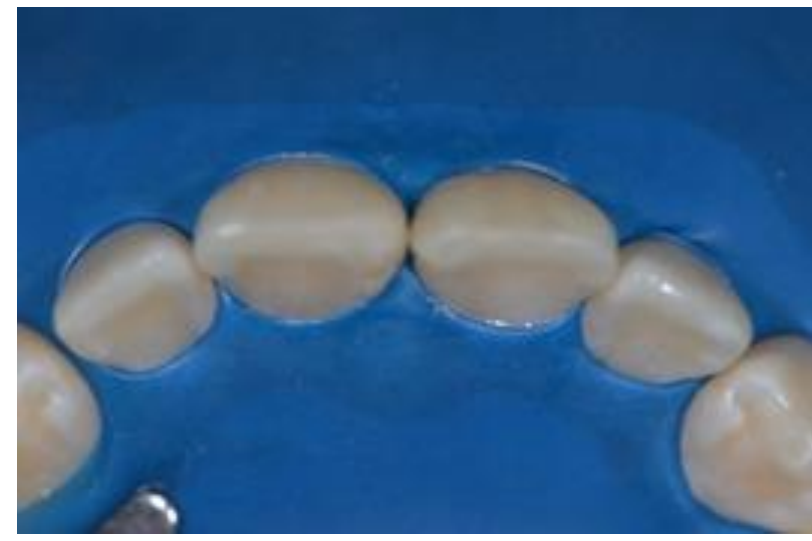

Figura 27: Construção da face palatina, vestibular e proximal, do elemento dentário 21 , com resina composta fotopolimerizável, vista por incisal.

Concluído a inserção dos compósitos, um último incremento, é aplicado e conformado, com auxílio de espátulas e pincéis. Confirmado o contorno da restauração que fecha o diastema realiza-se a fotoativação (Figura 28).

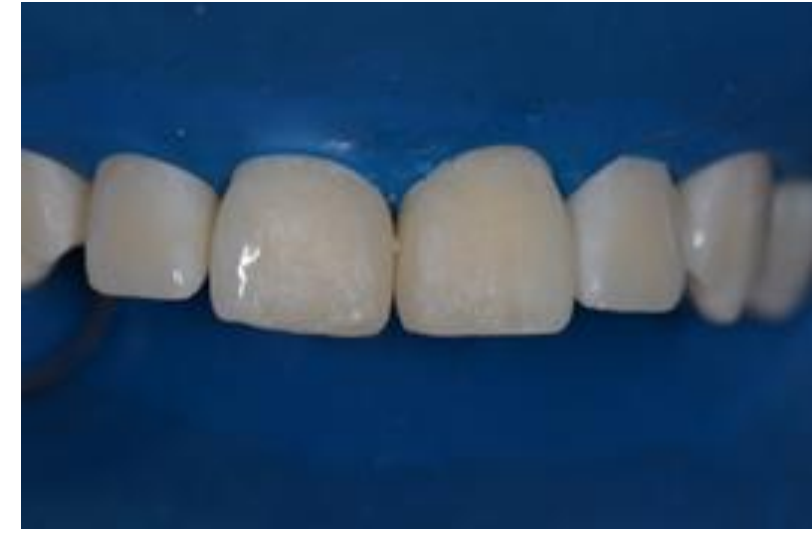

Figura 28: Fechamento completo do diastema entre incisivos centrais superiores.

Concluído o fechamento do diastema entre os dentes 11 e 21, a próxima etapa foi a do fechamento do diastema entre os dentes 12 e 13 (Figura 29).

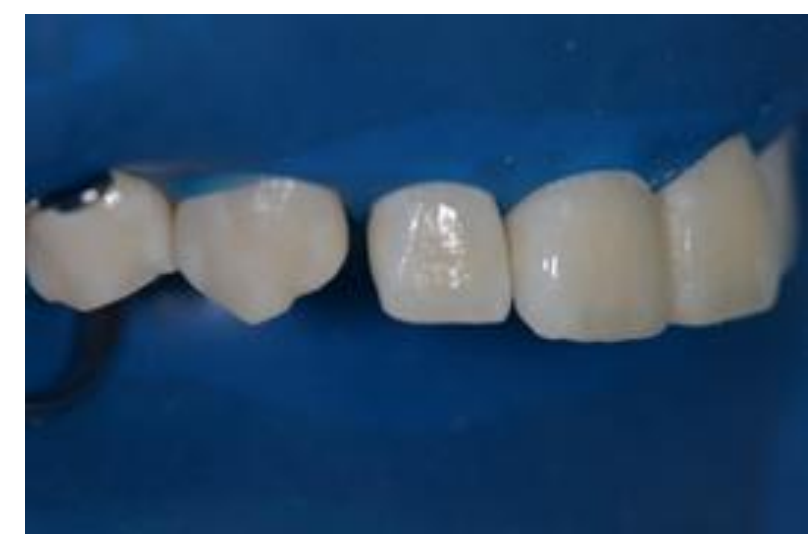

Figura 29: Foto inicial do diastema entre os elementos dentários 12 e 13 .

Os mesmos procedimentos realizados foram no dente 12 , sendo que o dente 13 foi protegido com fita de polipropileno (fita veda-rosca). O condicionamento ácido, lavagem, secagem e aplicação do sistema adesivo, foram realizados, de forma idêntica a descrita no procedimento anterior (Figuras 30 e 31).

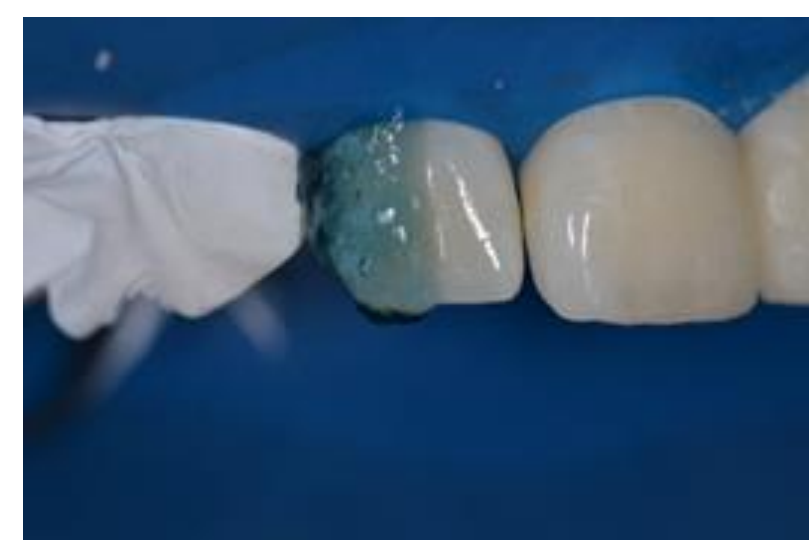

Figura 30: Condicionamento ácido por 30 segundos no elemento dentário 12. Superfície do dente adjacente protegida com fita veda rosca.

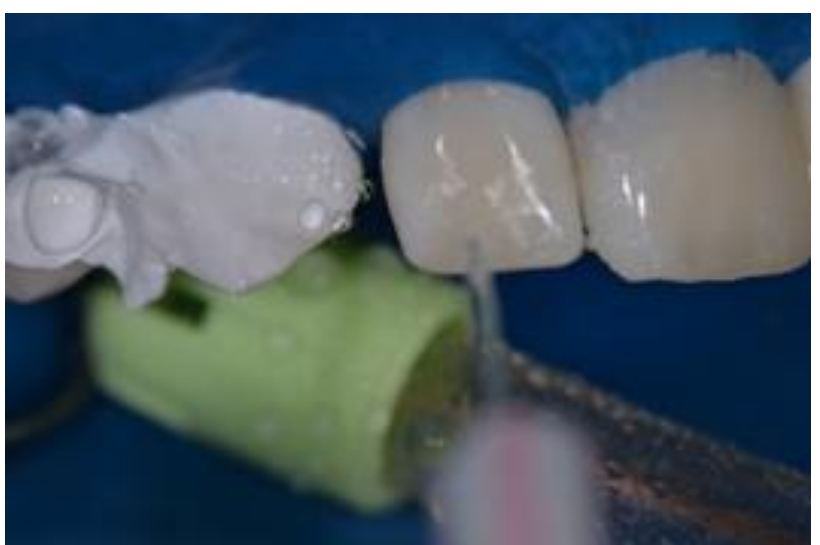

Figura 31: Lavagem com água, por 30 segundos, nas áreas condicionadas.

Antes de iniciar a construção da restauração com resina composta foram consideradas as medidas $\mathrm{e}$ proporções do elemento dentário 22 que é homologo e apresenta formato similar a ser considerado. Com isso se chegou a uma conclusão para diminuição significativa do diastema sem alterar o padrão estético (Figuras 32 a 34).

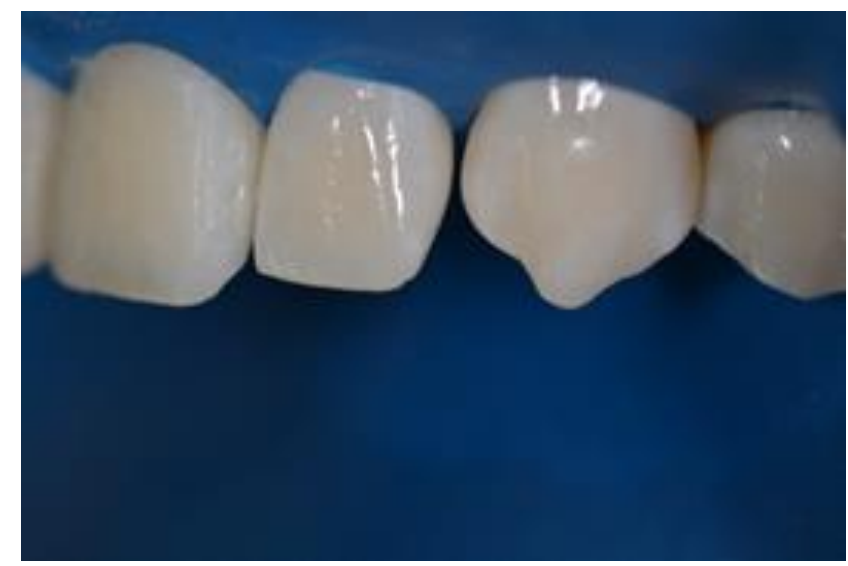

Figura 32: Foto do elemento dentário 22, que é o homologo do 12 , com padrão estético e formato similar a serem considerados no fechamento do diastema entre os elementos dentários 12 e 13.

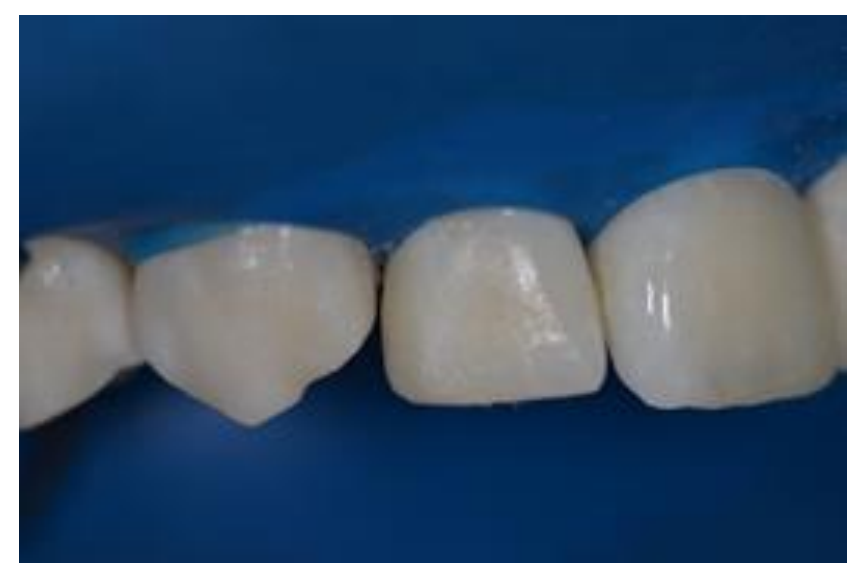

Figura 33: Termino da construção por palatina, vestibular e proxima com resina composta fotopolimerizável, no elemento dentário 12 da redução do diastema com elemento dentário 13.

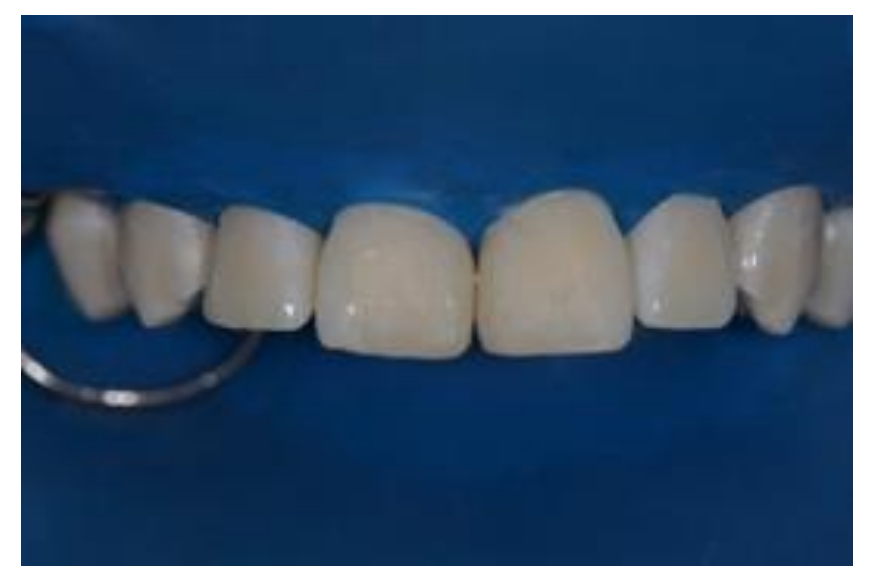

Figura 34: Aspecto antes do acabamento.

Após fotoativação final realizou-se o procedimento de acabamento das restaurações com brocas de acabamento fino de resina composta 2135 FF e 3118 FF. Após remoção do isolamento absoluto o procedimento de acabamento foi continuado para a remoção dos excessos. O paciente foi então orientado a voltar após uma semana para realizar o polimento final (Figuras 35 a 37). 


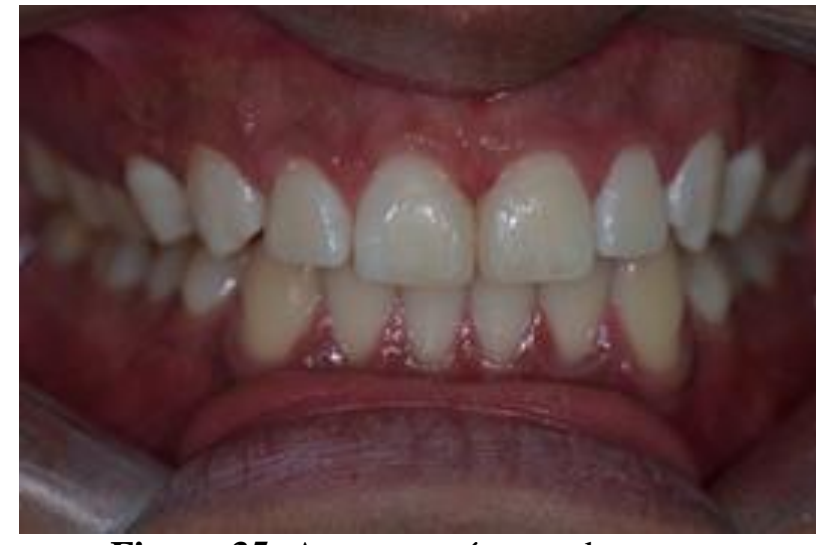

Figura 35: Aspecto após o acabamento.

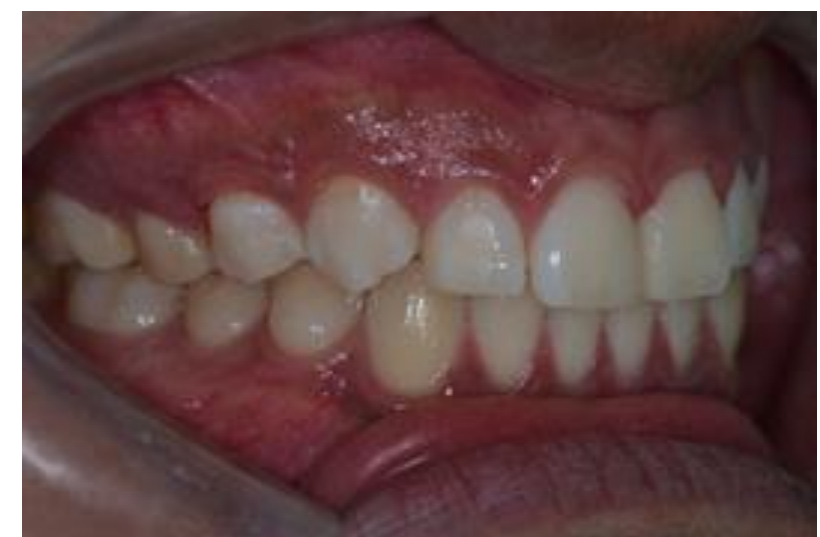

Figura 36: Aspecto do elemento dentário 12 após o acabamento.

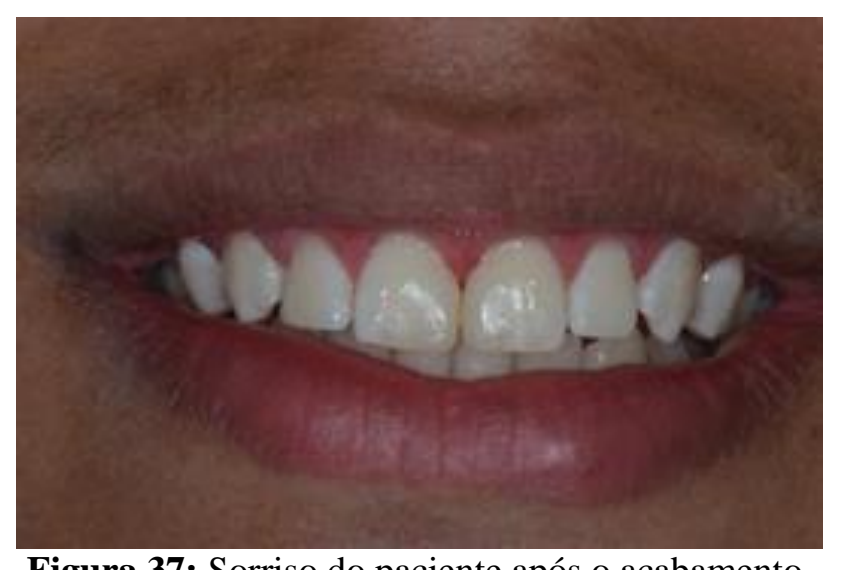

Figura 37: Sorriso do paciente após o acabamento.

Após 10 dias o paciente retornou para a realização do polimento. O procedimento foi iniciado utilizando pontas do Sistema de Acabamento Enhance (Dentsply Indústria e Comercio LTDA, Petrópolis-RJ, Brasil). Em seguida foram utilizados discos de feltros Diamond (FGM Denstcare, Joinville, SC, Brasil) com pasta de acabamento e prépolimento Diamond acI e Daimond acII (FGM Denstcare, Joinville-SC, Brasil) respectivamente (Figuras 38 a 40).

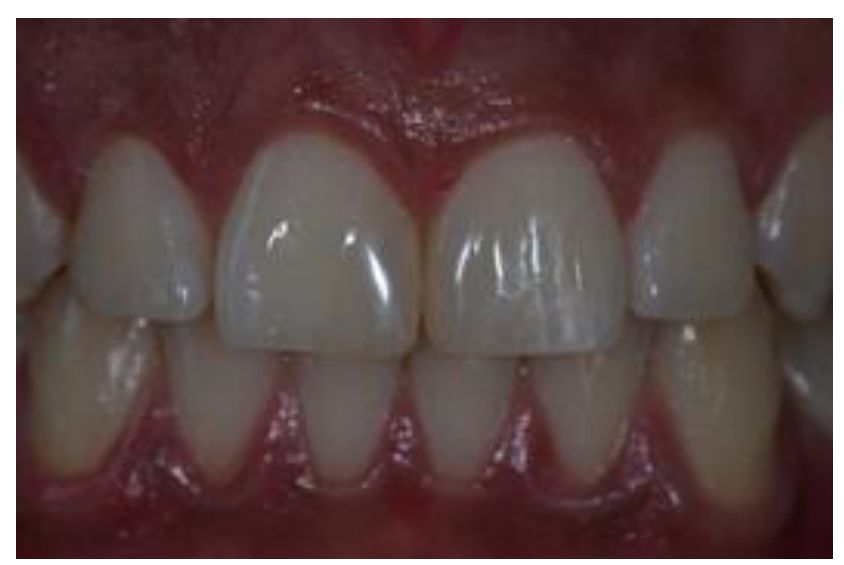

Figura: 38: Aspecto após o acabamento e polimento.

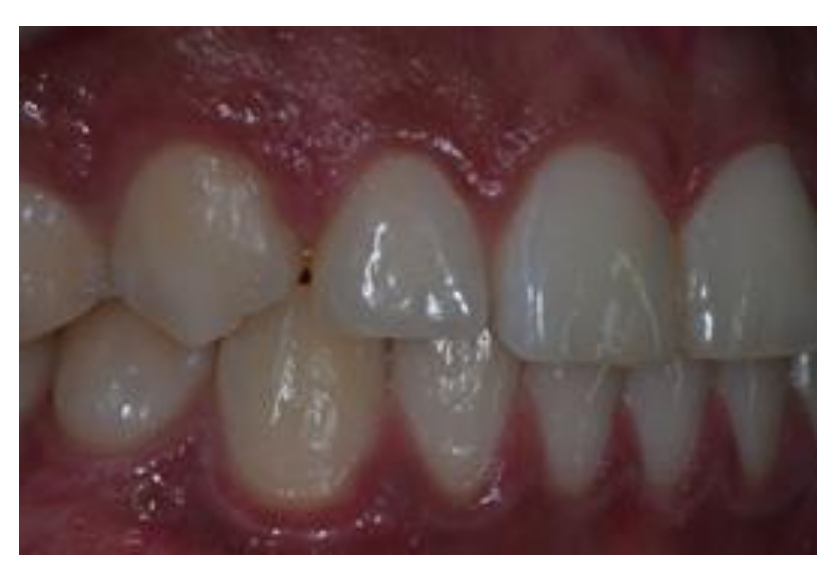

Figura: 39: Aspecto do elemento 12 após polimento.

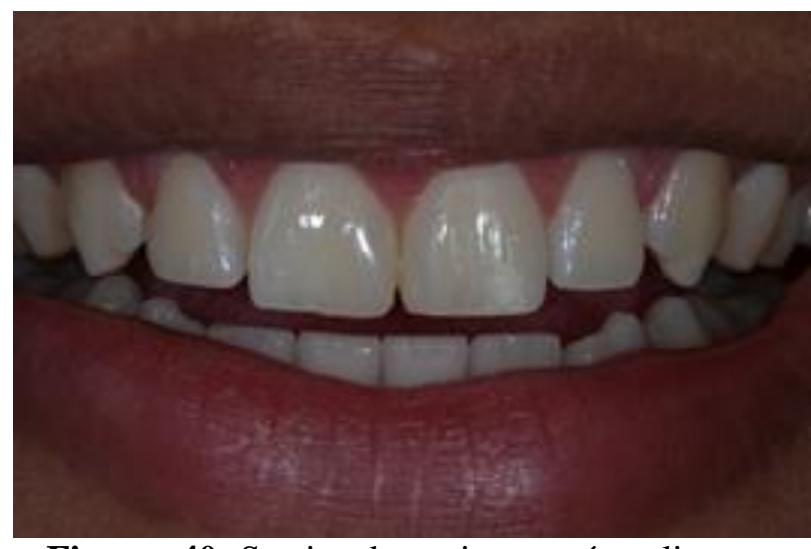

Figura: 40: Sorriso do paciente após polimento

Com a conclusão do tratamento restaurador estético o paciente relatou perceber benefícios ficando satisfeito com os resultados do procedimento. O paciente então teve sua alta do tratamento e encontra-se em proservação.

\section{DISCUSSÃO}

Diante das informações coletadas com anamnese, exame clínico e radiográfico para montagem do diagnóstico e analise do modelo de estudo, verificou-se que o diastema foi ocasionado pela interposição física do freio labial ${ }^{2}$. A distância no diastema medido, entre um dente e outro, nos incisivos centrais foi de $2,4 \mathrm{~mm}$ de diâmetro.

Também foi visto no exame histopatológico uma leve inflamação crônica inespecífica com alguns linfócitos no epitélio do sulco gengival, que pode ser atribuída a acúmulo de biofilme ${ }^{6}$, ou a trauma de escovação, proveniente da dificuldade da higiene do paciente na região.

Existem controvérsias entre os autores em relação ao momento ideal de intervenção para o freio labial hipertrófico, assim como a associação com o tratamento ortodôntico. Alguns autores ${ }^{7}$ preconizam a cirurgia após erupção dos caninos permanentes, enquanto outros ${ }^{16}$ recomendam após erupção dos incisivos laterais permanentes. No entanto, sugere-se intervenção cirúrgica na dentadura mista, após erupção dos incisivos centrais superiores e antes da erupção dos caninos superiores permanentes, caso haja associação a com freio labial hipertrófico e diastema interincisal.

Um sorriso natural e harmônico somente poderá ser estabelecido após uma análise das características individuais do paciente e, principalmente, ouvir o paciente quanto a suas necessidades e expectativas ${ }^{22}$. Nos casos cujos espaços interproximais dos dentes anteriores são muito acentuados, certamente promovem certo incômodo em relação à estética do sorriso para o paciente; sendo assim, este é um dos principais motivos pela procura de tratamento nos consultórios odontológicos ${ }^{17}$.

As diversas opções para o fechamento dos diastemas pode ser amplamente discutida e um dos pontos importantes para o plano de tratamento, nestes casos, é ouvir os anseios e desejos do paciente. Em um primeiro momento, a Ortodontia surge como primeira opção para a resolução destes casos, possibilitando em muitas situações o fechamento dos diastemas ${ }^{15}$. Por outro lado, outras opções devem estar preparadas para os casos em que o tratamento ortodôntico não é indicado ou até mesmo quando não existe o desejo do paciente por este tipo de tratamento ${ }^{20}$.

Seguindo este raciocínio, o tratamento restaurador surge como uma excelente opção, através da utilização da consagrada técnica do condicionamento ácido do esmalte/dentina ${ }^{9}$, dos eficientes sistemas adesivos e resinas compostas. As substanciais melhorias desses materiais têm possibilitado a realização de restaurações adequadas do ponto de vista biológico, estético e funcional ${ }^{19}$. 
Também não pode ser esquecida a relação das restaurações com os tecidos periodontais. Alterações no perfil de emergência devem ser feitas de forma diligente e cautelosa, sem produzir excessos que comprometam a saúde do periodonto. É essencial atentar para formação de papila interdental, que exige que o ponto de contato entre os dentes fique, no máximo, $5 \mathrm{~mm}$ distante da crista óssea ${ }^{23}$.

Finalmente, a escolha do melhor material restaurador para utilização de forma direta deve ser feita com critérios, a fim de se estabelecer novas dimensões e larguras mesiodistais semelhantes às estruturas naturais já presentes nos elementos dentais, como cor, textura e resistência ${ }^{15,16,19,21,22}$. A evolução das resinas compostas favoreceu muito a utilização destas na região anterior, devido às suas características ópticas e mecânicas serem muito semelhantes ao da estrutura dental ${ }^{19}$.

\section{CONCLUSÃO}

Concluiu-se que presente relato de caso clínico apresentou alternativas seguras e eficazes de tratamento cirúrgico aliado a procedimentos restauradores na resolução do freio labial hipertrófico associado ao respectivo diastema, podendo ainda ser considerado como um tratamento conservador, estético e funcional possibilitando ao jovem paciente a satisfação de sorrir sem receios.

\section{REFERÊNCIAS}

1. Vanzato JW, Sampaio JEC, Toledo BEC. Prevalência do freio labial anômalo e diastema mediano dos maxilares e sua interrelação. Rev Gaúch Odontol. 1999; 47(1):27-34

2. Costa HS, Farias IOB, Cardoso CG. Frenectomia labial superior como terapia no fechamento interincisal. Rev Assoc Paul Cir Dent. 2009; 63(4):308-3.

3. Peterson JL, Hupp R, Tucker MR. Cirurgia Oral e Maxilo-Facial Contemporânea, 3. ed. Rio de Janeiro: Elsevier; 2000.

4. Ferreira FV. Ortodontia: Diagnostico e Planejamento clínico. São Paulo: Artes Médicas; 2001. p 246-247.

5. Valladares Neto J, Ribeiro AV, Silva Filho OG. O dilema do diastema mediano e freio labial superior: Análise de pontos fundamentais. ROBRAC. 1996; 6(19):9-16.

6. Edwards JG. The diastema, the frenum, the frenectomy: a clinical study. Am J Orthod. 1977; 71(5):489-508.

7. Cavalcante JA, Xavier P, Mello-Moura ACV, Alencar CJF, Imparato JCP. Diagnóstico e tratamento cirúrgico do freio teto labial persistente em pacientes no período intertransitório da dentição mista - relato de caso. Rev Inst Ciênc Saúde. 2009; 27(3):290-4.

8. Komatsu J, Russo M. Restaurações estéticas em dentes anteriores sem preparo cavitário convencional: estudo clínico. Rev Assoc Paul Cir Dent. 1979; 33(5):386-92.

9. Swift JR, Perdigão J, Heymann HO. Bonding to enamel and dentin. A brief history and state of the art, 1955. Quintessence Int. 1995; 26(2):95-110.

10. McDonald RE. Avery DR. Odontopediatria. São Paulo: Artes Médicas; 1995. p.107-9

11. Walter LRF. Odontologia para o bebê. São Paulo: Artes Médicas; 1996. p.58.

12. Duarte DA, Bönecker M, Corrêa FNP, Corrêa MSNP. Cirurgia bucal em pacientes pediátricos. In: Corrêa MSNP. Odontopediatria na primeira infância. 2. ed. São Paulo: Santos; 2005. p.629-44

13. Fonoff RDN, Haddad AE, Alencar CJF. Cirurgia em Odontopediatria. In: Guedes-Pinto AC, Bonecker M, Rodrigues CRMD. Fundamentos de Odontologia Odontopediatria. São Paulo: Santos; 2009. p. 277-99.

14. Kelman MB, Duarte CA. O freio labial superior e a sua influência na ortodontia e periodontia: revisão da literatura. Rev Assoc Paul Cir Dent. 1991; 45(5):581-4.

15. Almog D, Sanchez Marin C, Proskin HM, Cohen MJ, Kyrkanides S, Malmstrom H. The effect of esthetic consultation methods on acceptance of diastema-closure treatment plan: a pilot study. J Am Dent Assoc. 2004; 135(7):875-81

16. Perdigão J, Geraldeli S, Heymann HO, Rosa BT. Effect of conditioner and restorative resin on enamel bond strengths. Am J Dent. 2000; 13(2):88-92.

17. Okida RC, Silveira Okida DS, Machado LS. Emprego de técnica cirúrgica e materiais adesivos no fechamento de diastemas. RPG Rev Pós Grad. 2011; 18(1):57-61.

18. Haddad AE, Fonoff RN. Freio teto-labial persistente Diagnóstico e tratamento cirúrgico. J Bras Odontopediatr Odontol Bebê. 2000; 3(19):125-9.

19. Sundfeld RH, Sundfeld Neto D, Rahal V, Pita DS, Okida RC, de Alexandre RS. Different esthetic techniques used in combination to improve the smile. Compend Contin Educ Dent. 2010; 31:1-2.

20. Furuse AY, Franco EJ, Mondelli J. Esthetic and functional restoration for an anterior open occlusal relationship with multiple diastemata: a multidisciplinary approach. J Prosthet Dent. 2008; 99(2):91-4.

21. Komatsu J, Russo M, Takayama S, Holland Junior C, Sasaki T, Quintella LA. Influência da contaminação do esmalte dental descalcificado pelo ácido na retenção de restaurações de resinas compostas. Rev Assoc Paul Cir Dent. 1980; 34(6):476-9.

22. Levin EI. Dental esthetics and the golden proportion. J Prosthet Dent. 1978; 40(3):244-52.

23. Baratieri LN. Odontologia restauradora: fundamentos e técnicas. São Paulo: Santos; 2014.

\section{CONFLITO DE INTERESSES}

Os autores declaram não haver conflitos de interesse.

\section{AUTOR PARA CORRESPONDÊNCIA}

Jean Jacques da Silva Andrade

jacjean74@gmail.com
Submetido em 14/08/2017

Aceito em 28/09/2017 